\title{
Development of human capital in the context of improving processes in the enterprise
}

\author{
Rafal Prusak ${ }^{1, *}$ \\ ${ }^{1}$ Czestochowa University of Technology, Faculty of Production Engineering and Materials \\ Technology, Department of Production Management and Logistic, Poland
}

\begin{abstract}
Human is the key resource of the organization, and proper human resources management, manifested primarily by matching knowledge, skills and attitudes of employees to the strategic goals of the company should lead to their transformation into human capital and the synergy effect of combining the qualities and strengths of employees intensifying the frequency of the innovative concepts. The main purpose of the article is to present the results of research conducted on a sample of 70 enterprises regarding the analysis of the extent of enterprises' use of the potential accumulated within human capital to improve the implemented processes, including quality management. The research covered issues related to the impact of the functioning of the human resources management system on the company efficiency, the main factors supporting and hindering the functioning of this system, as well as problems and difficulties occurring both at the stage of implementing the system and its subsequent operation. The basic research tool was a questionnaire consisting of 23 questions of a closed nature supported by interviews conducted with representatives of the management. The article also includes a literature review on selected aspects of shaping and managing human capital and increasing the professional potential of employees as a result of systemic management of their competences.
\end{abstract}

\section{Introduction}

According to modern management theories [1], the reality in which enterprises operate is characterized by such statements as: enterprises need people, intellectual advantage (including human capital) determines the competitive advantage, employees are mobile, and their relationship with the enterprise is not long-term, employees expect to meet diverse needs. Properly motivated people are able to use their knowledge and experience to actively participate in the process of achieving the goals of the company as an important source of building market advantage [2]. In this context, it is important to treat all employees as a source of potential opportunities and to make them aware of their strengths and weaknesses, indicating the areas in which their work will be the most valuable for the company [3]. The company must strive to make the employee voluntarily focus his efforts on the company's goals [4]. The role of employees' involvement was clearly emphasized in

\footnotetext{
* Corresponding author: prusak.rafal@wip.pcz.pl
} 
the works by Beer and Spector, according to the model [5]: people are able to develop only when they operate in a favorable work environment, the key to building trust and commitment is to ensure open communication, greater employee engagement is achieved when they take part in identifying problems and finding solutions, it is important to have a personnel strategy combining employee goals with the company's goals.

Human resource management is understood as a strategic, coherent and integrated approach to the employment, development and quality of life of employees employed in the enterprise [6]. It is a kind of a system in which people's problems and goals are combined with the goals of the organization [7] and a human is treated as the key assets of the company and the source of its competitiveness occupying a central place in management processes [8]. Proper management of human resources therefore requires constant actions aimed at improving the knowledge about the skills and potential of employed people in order to be able to fully use their experience and competences for the benefit of the company and employees. Proper management of human resources is a key aspect of the process in which these resources are transformed into human capital [9].

In literature, human capital is defined in a rather broad way, taking into account different criteria, perspectives and scale. An overview of available theories allows to conclude that human capital:

- is a set of specific features and properties embodied in employees that have a certain value and are a source of future income for both the employee - the owner of human capital, and for the organization that uses certain capital on certain terms [9],

- $\quad$ is the main source of value and the factor determining the competitive position and is the only type of capital that can add to itself and by itself [10],

- includes combined knowledge and innovation of employees [11], competencies important in business [12], social and personal skills [13], physical, mental, intellectual and moral characteristics shaped by predispositions and internal motivation [14], innate human abilities, specific behavioral patterns and personal energy of the employee [15],

- $\quad$ is used as a result of synergic impact of ability, experience, creativity [6],

- relates strongly to performance, especially when the human capital in question is not readily tradable in labor markets and when researchers use operational performance measures that are not subject to profit appropriation [16], requires shaping appropriate attitudes of employees [17], takes into account intellectual attributes, commitment, behaviour ethics, leadership and other social predispositions to specific organizational behaviours [8],

- uses both the ability to analyze and synthesise [18] leading to the development and introduction of innovations in the enterprise [19],

- cannot become the property of an enterprise because it is closely related to specific persons, it only remains in its temporary disposal [11].

The value of human capital depends to a large extent on the level of employees' involvement, the degree to which they want to and can use their own potential to achieve the company's goals. Therefore, the key factor in this context is to ensure an appropriate level of employee motivation and professional satisfaction, which is a consequence of the synergistic impact of organizational culture, management style, terms and content of work, interpersonal relations and incentives within the incentive system.

Human capital can be perceived in three basic perspectives [20]:

- economic one, according to which human capital is specific, it is uncertain, and the actions of enterprises (connected with incurring costs) should focus on the selection of appropriate employees,

- human capital - placing emphasis on decisions regarding the level of outlays on investments in human capital, 
- $\quad$ resource based, based on the study of competitive advantage resulting from the proper use of human resources.

Human capital management consists in making decisions (strategic, investment, operational, adding value) concerning the management of people based on acquired, analyzed and reported data [6]. At the same time, it is a set of activities aimed at the productive use of the company's abilities perceived as key to achieving current and future successes [21].

In the context of effective human capital management, literature often raises the issue of proper development of employees and the proper use of their knowledge, experience or generally speaking - competence. Competences are defined as modifiable and adjusted to the requirements of the position, predispositions [9], and distinctive behavior of employees in various professional situations, determined by the knowledge and skills they use, and by attitudes and motivations [22] that allow him to effectively carry out professional tasks [23].

The main objectives of competence management can be included [24]:

- defining competence standards for workstations,

- examining the real competences of employees and job candidates in terms of job selection,

- preparing people in the organization for current and future tasks,

- increasing the value of the organization by increasing the value of human capital,

- increasing the level of employee satisfaction,

- maximum use of employees' strengths while minimizing their weaknesses,

- optimization of the relation: expenditures on human capital - effects.

\section{Methodology and analysis of results}

The main purpose of this study is to attempt to characterize selected relationships between the company's activities undertaken in the context of raising the level of employees' competences and selected strategic variables. The research was conducted using a questionnaire and a structured interview in 70 companies representing various sectors and characterized by different market situation. The survey consisted of 23 questions. The questionnaire was filled by representatives of the top management in each of the research facilities in the presence of the person conducting the research (some issues were discussed, answers were given to possible doubts of management representatives). The selection of the research sample was deliberate.

In this study, only selected elements of the study were characterized, the results of which are presented in Table 1 concern:

- impact of the introduction of the competence management system on the organization's efficiency: imperceptible (1.1), small (1.2), significant (1.3), large (1.4), very large (1.5),

- factors that have the greatest impact on the functioning of the competency management system: involvement of senior management (2.1), connection with the incentive system (2.2), awareness of employees about the role and importance of the system (2.3), properly developed training system (2.4), visible effects of the system (2.5), allocation of the appropriate amount of resources (2.6),

- elements that hinder the functioning of the system to the greatest extent: no management involvement (3.1), insufficient employee involvement (3.2), system mismatch (3.3), insufficient resources (3.4), poor selection of training units (3.5), no consequences in activities (3.6), no connection with other systems in the enterprise (3.7), 
- elements contributing to problems during the development of the system: lack of staff motivation (4.1), inability to identify connections with other systems (4.2), difficulties in finding a consulting company (4.3), inability to select methods and techniques (4.4), incorrectly defined ranges liability (4.5), previous negligence and lack of action (4.6).

Table 1. Summary of research results.

\begin{tabular}{|c|c|c|c|c|c|c|c|c|c|}
\hline \multirow[b]{2}{*}{ No. } & \multicolumn{3}{|c|}{ Intensity of competition } & \multicolumn{3}{|c|}{$\begin{array}{c}\text { The bargaining power } \\
\text { of suppliers }\end{array}$} & \multicolumn{3}{|c|}{$\begin{array}{c}\text { The bargaining power of } \\
\text { recipients. }\end{array}$} \\
\hline & low & avg & high & low & avg & high & low & avg & high \\
\hline 1.1 & 2 & 6 & 1 & 0 & 1 & 8 & 1 & 5 & 3 \\
\hline 1.2 & 2 & 4 & 1 & 0 & 1 & 6 & 0 & 4 & 3 \\
\hline 1.3 & 8 & 12 & 2 & 1 & 12 & 9 & 2 & 19 & 1 \\
\hline 1.4 & 0 & 11 & 7 & 1 & 15 & 2 & 2 & 10 & 6 \\
\hline 1.5 & 1 & 2 & 11 & 1 & 11 & 2 & 0 & 4 & 10 \\
\hline 2.1 & 0 & 5 & 15 & 1 & 17 & 2 & 0 & 7 & 13 \\
\hline 2.2 & 2 & 6 & 0 & 2 & 3 & 3 & 1 & 6 & 1 \\
\hline 2.3 & 2 & 1 & 0 & 0 & 0 & 3 & 0 & 3 & 0 \\
\hline 2.4 & 3 & 2 & 0 & 0 & 1 & 4 & 0 & 5 & 0 \\
\hline 2.5 & 2 & 9 & 4 & 0 & 10 & 5 & 1 & 10 & 4 \\
\hline 2.6 & 5 & 11 & 3 & 0 & 8 & 11 & 3 & 11 & 5 \\
\hline 3.1 & 7 & 10 & 2 & 0 & 8 & 11 & 2 & 15 & 2 \\
\hline 3.2 & 3 & 10 & 5 & 1 & 12 & 5 & 1 & 9 & 8 \\
\hline 3.3 & 3 & 4 & 4 & 0 & 7 & 4 & 0 & 8 & 3 \\
\hline 3.4 & 1 & 5 & 8 & 1 & 6 & 7 & 1 & 6 & 7 \\
\hline 3.5 & 0 & 1 & 1 & 0 & 2 & 0 & 0 & 1 & 1 \\
\hline 3.6 & 0 & 2 & 1 & 0 & 2 & 1 & 1 & 1 & 1 \\
\hline 3.7 & 0 & 2 & 1 & 1 & 2 & 0 & 0 & 2 & 1 \\
\hline 4.1 & 1 & 9 & 5 & 1 & 9 & 5 & 1 & 9 & 5 \\
\hline 4.2 & 4 & 12 & 1 & 1 & 9 & 7 & 0 & 13 & 4 \\
\hline 4.3 & 3 & 1 & 0 & 0 & 1 & 3 & 0 & 4 & 0 \\
\hline 4.4 & 2 & 5 & 4 & 0 & 6 & 5 & 2 & 6 & 3 \\
\hline 4.5 & 1 & 2 & 4 & 0 & 5 & 2 & 1 & 3 & 3 \\
\hline 4.6 & 3 & 5 & 8 & 1 & 9 & 6 & 1 & 7 & 8 \\
\hline
\end{tabular}

The obtained results allowed to state the following basic trends and phenomena:

- Regardless of the strategic criterion applied, the introduction of a competency management system - in accordance with the declarations of the management personnel - had a significant impact on the efficiency of the organization's functioning. Among others, there were: fewer mistakes and errors of employees, reduced number of defective products (according to company data from several to several dozen percent), reduced number of customer complaints and general slight increase in their satisfaction level.

- The most frequently indicated factors affecting the functioning of the competence management system were: engagement of senior management (both in the supervision dimension and active inclusion in the consultation process and improvement), visible 
effects of the system (significantly improving morale and the level of employee motivation), appropriate the amount of resources (both tangible and intangible).

- Among the most-difficult elements of the system's functioning, the following were pointed out, among others: insufficient employee involvement (especially in the context of consolidation of implemented practices and feedback), system mismatched to the company's needs (as a result of excessive reliance on standard, model or theoretical solutions).

- The most important elements contributing to the problems during the development of the system were: lack of staff motivation (mainly following an ineffective organizational culture, inappropriate management styles or too low involvement of employees in the development and implementation of the system), inability to identify connections with other systems (lack of experience in implementing such solutions, inadequate management methods), and previous negligence and lack of actions (a number of elements, including: fixed erroneous patterns of actions, disregard of intangible assets, high employee turnover, ineffective remuneration system).

\section{Conclusions}

According to contemporary theories in the area of organization and employment, people are a key resource of enterprises. It results from the accumulated potential in them which is a resultant of the effects of the education process, previous professional experience and personality traits (including openness to changes, willingness to participate in prodevelopment activities). Effective human capital management is able to bring measurable and satisfying benefits to the company. The basic ones include: more effective use of knowledge and competences of employees, increasing the number of pro-innovative activities (as a result of better knowledge management, effective team building, functioning of a stimulating organizational culture), improving the market situation, building unique market advantages, improving market image and customer relations.

The conducted research allowed to show that in almost half of the analyzed enterprises, the effect of implementing the human capital management process were significant changes affecting the efficiency of the company's operation, in some cases leading to a change in the strategic approach. Nearly one-third of the respondents pointed to the occurrence of significant effects in the area of quality in the production process. Research has shown that the efficiency of using the human factor in enterprises operating in difficult market conditions is greater and that there is a possibility of occurrence of large potential benefits in the area of interpersonal relations and the effectiveness of work of employee teams. At the same time, enterprises operating in more difficult market conditions declared greater interest in targeted development of individual and group employee competences.

Undoubtedly, the statement of the existence of clear statistical dependencies will require conducting additional, extended research using a more complex research apparatus. A more detailed recognition of individual elements and a more precise characterization of existing relationships and dependencies of both an internal and external character will be necessary. Human capital and its management processes are becoming an everyday reality for modern enterprises. Obtaining unique market advantages due to them can ensure the strengthening of the market position and increase the profitability of functioning. It is important, however, that issues related to this area be permanently integrated with the basic strategy of the company. From the point of view of the interests of the company, human capital at the team level is particularly interesting. in this area, the competence of employees and the exchange and development of knowledge are combined. Synergic impacts of potentials of individual employees can lead at this level to obtaining above-average and unexpected results and 
performance. The task of the company is to create a working environment that allows for the most free and uninterrupted exchange of ideas and the integration of employees.

\section{References}

1. E. Michaels, H. Handfield - Jones H., B. Axelrod, The War for Talent (Harvard Business School Press, Boston, 2001)

2. E. Michaels, H. Handfield - Jones H., B. Axelrod, Strategic HRM: The route to improved business performance (IP, Londyn, 2002)

3. M. Adamiec, B. Kożusznik, Zarządzanie zasobami ludzkimi (Akade, Kraków, 2000)

4. B. A. Campbell, R. Coff, D. Kryscynski, Academy of Management Review 37, 3 (2012).

5. O. Lundy, A. Bowling, Strategiczne zarzadzanie zasobami ludzkimi (Dom Wydawniczy ABC, Oficyna Ekonomiczna, Kraków, 2001)

6. M. Armstrong, S. Taylor, Zarządzanie zasobami ludzkimi (Wolters Kluwer, Warszawa, 2016)

7. N. McKenna, E. Beech, Zarządzanie zasobami ludzkimi (Gebethner i Spółka, Katowice, 1998)

8. A. Pocztowski, Zarzadzanie zasobami ludzkimi, Strategie - procesy - metody (PWE, Warszawa, 2006)

9. H. Król, A. Ludwiczyński, Zarządzanie zasobami ludzkimi, Wydawnictwo Naukowe PWN, Warszawa, 2014)

10. J. Fitz-enz, The ROI of Human Capital (AMACOMNowy Jork, 2000)

11. L. Edvinsson, M. Malone, Intellectual Capital (Harper Collins Publishers, New York, 1997)

12. Human Capital Investment. An International Comparision, Centre for Educational Research and Innovation, OECD, 1998)

13. J. K. Mawdsley, D. Somaya, Journal of Management 42, 1 (2016).

14. A. Pietruszka - Otryl Wyzwania wartościowania kapitatu intelektualnego organizacji, in: E. Skrzypek (ed.), Uwarunkowania sukcesu przedsiębiorstw w gospodarce opartej na wiedzy (Wydawnictwo UMCS w Lublinie, Lublin, 2004)

15. T. O. Davenport, Human Capital: What It Is and Why People Invest It (Jossey-Bass, 2008).

16. T. Crook, T. Russell, Y. Samuel, J. G. Combs, D. J. Woehr, D. J. Ketchen Jr., Journal of Applied Psychology 96, 3 (2011).

17. B. A. Campbell, M. Ganco, A. M. Franco, Strategic Management Journal 33, 1 (2012).

18. J. Roos, G. Roos, N.C. Dragonetti, Intelectual Capital - Navigating in the Business Landscap (Macmillan Press, London, 1997)

19. A. Baron, A. Armstrong, Zarzadzanie kapitałem ludzkim. Uzyskiwanie wartości dodanej dzięki ludziom (Woltes Kluwer, Warszawa, 2012)

20. L. Yaping, J. Jingfang, Management Science and Engineering 1, 2 (2007)

21. D. Whitaker, Personnel Today, 2 (2007).

22. S. Borkowska, Strategie wynagrodzeń (Oficyna Ekonomiczna, Dom Wydawniczy ABC, Kraków, 2001)

23. C. Woodruffe, Ośrodki oceny i rozwoju (Oficyna Wydawnicza, Kraków, 2003)

24. T. Oleksyn, Zarządzanie kompetencjami. Teoria i praktyka (Wolters Kluwer Polska, Warszawa, 2010) 